\title{
ASEAN Journal of Science and Engineering
}

Journal homepage: http://ejournal.upi.edu/index.php/AJSE/

\section{Benefits and Effectiveness of Automatic Farmer Pest Repellent}

\author{
Krisna Dwi Nurikhsani ${ }^{1},{ }^{*}$, Jonah Mupita ${ }^{2}$ \\ ${ }^{1}$ Departemen Pendidikan Teknik Elektro, Universitas Pendidikan Indonesia, Bandung, Indonesia \\ ${ }^{2}$ Ruya Adventist High, Zimbabwe \\ *Correspondence: E-mail: krisnadn132@upi.edu
}

\begin{abstract}
A B S T R A C T
Indonesia is one of the countries that is famous for its extensive agricultural land so it is not surprising that Indonesia is called an agrarian country. In addition, most of the population earns a living as farmers, but this does not make Indonesia the largest rice producer in the world. Apart from that, farmers in Indonesia have difficulty dealing with pests that make them suffer losses due to crop failure. This study aims to explain the benefits and effectiveness of an automatic tool that can repel farmer pests, especially rats and birds. In this tool there is a Passive Infrared Receiver sensor that functions to detect the presence of farmer pests, then the servo motor will activate the bell, and pull the bell to produce a sound that scares birds and mice. The mechanism is controlled by a microcontroller, namely Arduino ATmega 2560. This tool is an innovation from previous technologies so that farmers' problems regarding farmer pests can be solved easily.
\end{abstract}

ARTICLE INFO

Article History:

Submitted/Received 29 Jun 2021

First revised 07 Aug 2021

Accepted 09 Oct 2021

First available online 11 Oct 2021

Publication date 01 Dec 2022

Keyword:

Arduino,

Farmer,

Innovation,

Pest,

Technology. 


\section{INTRODUCTION}

Farmer pests are still the biggest problem for Indonesian farmers because farmer pests cause many farmers to suffer losses. Based on the information we got from surabaya.tribunnews.com on July 2, 2020, around 143 hectares of rice fields in Lamongan were attacked by Satroni rats, causing large losses to farmers. The farmers admit that their agricultural products have suffered losses of up to hundreds of millions of rupiah.

The farmers have lost operational costs, such as the cost of procuring seeds, land preparation, planting, fertilizers, pesticides, and other costs. Various ways have been done by farmers to minimize rat attacks, ranging from holding a night wheel, telling children to play around the fields, to hunting rats directly. Unfortunately, this method did not have a major impact on their rice plants. At harvest time, farmers still suffer losses of up to tens of millions of rupiah.

From these problems, three students from Universitas Pendidikan Indonesia made an automatic farmer pest repellent. This tool is expected to overcome the problem of farmer pests that often make farmers experience losses. If the problem of farmer pests can be overcome, of course, rice production in Indonesia will increase, even the potential for Indonesia to become the largest rice-producing country in the world will increase. The tool is very effective and efficient because it works automatically, so farmers only need to attach it to the rice field area.

The tool was developed with a prototype controlled by Arduino technology, a PIR sensor (Passive Infrared Receiver) as a pest detector, a servo motor as a bell driver, and a buzzer with a frequency range of $38 \mathrm{KHz}-40 \mathrm{KHz}$ as additional features to increase the effectiveness of this tool. In this article, we intend to measure the benefits and efficiency of the prototype we create by comparing it to the previous technologies, looking at the potential of this prototype in reducing rice pests so that farmers would not experience crop failures anymore, and seeing how bad the impact of rice pests on Indonesian farmers' crops is.

\section{METHODS}

The method in this study is the descriptive method. With this method, we describe the benefits and effectiveness of the prototype automatic rice repellent. We conducted a literature study by looking for relevant references. The literature used is in the form of articles, journals, and online news. Then compare previous technologies to get a benchmark for the benefits and effectiveness of these devices.

\section{RESULTS}

\subsection{Rice Plant Pests}

Pests are often defined as harmful and unwanted organisms in human daily activities. Although basically pests can be associated with various kinds of organisms both in humans, animals, and plants, in practice, the term pest is more often used for animals. An animal can be called a pest if it causes damage to natural ecosystems or becomes an agent of the spread of disease in human habitats. In agriculture, pests are plant-disturbing organisms that cause physical damage, causing farmers to suffer a lot of losses. In the cultivation of rice plants, of course, farmers cannot be separated from various threats of pests that often attack their rice plants. Some types of pests that often damage rice plants include: 
(i) Rat. rat pests attack rice plants from the start as seeds until the plants enter the grainfilling period. Rats actively attack rice at night and during the day they hide in holes in irrigation embankments, rice fields, yards, shrubs, or weeds. With very fast-breeding, the damage caused by mice will be very detrimental. In the worst conditions, rats can cause rice plants to fail. One of the most effective ways to control rat pests is to take advantage of their natural enemies, namely snakes (Sayuthi et al ., 2020).

(ii) Bird. bird pests attack plants in the ripening phase until rice is harvested. Birds will eat directly the yellow rice grains, causing direct yield loss. In addition, birds also cause broken rice panicles. Control of bird pests can be done by eviction by making red markers around the rice fields or by using ropes hung from cans/plastic to make sounds that can repel birds or by using nets installed on the rice fields (Rainiyati \& Aryanda, 2015).

(iii) Leptocorisa oratoria. Leptocorisa oratoria is also known as rice ear bug will attack when the rice plant has entered the milk ripening phase. This pest will attack the rice grains by sucking the liquid so that the resulting rice is empty, wrinkled, brown, and tastes bad. With severe attacks, rice yields will be bad and reduce crop productivity. If not controlled immediately this pest will grow very quickly and cause huge losses. Control can be done by collecting and destroying Walang sangit eggs and by releasing natural enemies such as crickets and spiders (Rainiyati \& Aryanda, 2015).

(iv) Scirpophaga incertulas. the yellow stem borer is also known as rice yellow stem borer. The attack usually occurs in the vegetative phase, marked by the middle leaves or plant shoots dying because the growing point is eaten by stem borer larvae. The presence of these pests is characterized by the presence of moths and death in rice shoots. To control it can use mechanical methods, control by using biological methods and insecticides (Rainiyati \& Aryanda, 2015).

(v) Planthopper. planthopper pests have various types, including brown leafhoppers, white leafhoppers, and green leafhoppers. Planthoppers attack by sucking the liquid in rice plants and can transmit the virus to plants. This attack can cause the rice to become dry like a burning or its growth to be stunted (Rainiyati \& Aryanda, 2015).

(vi) Snails. snail pest attacks rice plants during the vegetative period and it starts from the seedling period. Snails damage plants by grating plant tissue and eating them, causing the loss of seeds per plantat mauris nulla. Aliquam ullamcorper metus eu dui auctor pulvinar. Vestibulum id ligula at lacus auctor euismod (Rainiyati \& Aryanda, 2015).

\subsection{Manual Farmer Pest Control}

Pests cannot be avoided, because they are living things that continue to develop according to their nature. Humans only control it and cannot eliminate it. Farmer pests control tools that have been made by farmers so far still use the manual method. For generations, farmers control pests, especially birds, by attaching a rope to a plastic bag or other objects, then spreading it over their rice field. The end of the rope is tied to the rice field bund area separately and the base is tied together at one point. This controller has a manual system because the rope can move when moved by the farmer. 
When the base of the rope is moved by the farmer, the entire rope will move simultaneously with the objects that are hung. As a result, the bird will be surprised and fly. However, this method is certainly very inefficient because farmers must always be in the fields to move the rope manually. In addition, the method that is still often found today is to install a scarecrow in the middle of the rice field area with the aim that the scarecrow can scare away bird pests that interfere with rice plants.

\subsection{Automatic Farmer Pest Control}

Technology continues to develop, manual tools become automated, and human work becomes lighter. Many farmers are still using manual midges. It would be nice, farmers began to realize how useful current technological developments are, and take advantage of these developments into an advantage and convenience to repel farmer pests. Therefore, students from the Department of Electrical Engineering Education from the Indonesian Education University (Universitas Pendidikan Indonesia) made an automatic farmer pest repellent, which can help farmers reduce the risk of losses due to bird and rat pests.

Automatic farmer pest repellent is the answer to the problems above, that is a tool that functions to repel farmer pests automatically, in the form of birds and mice. This tool, based on Arduino technology and sensors, uses a DC motor coupled with a bell and uses a buzzer feature. With the presence of this automatic rice repellent, it is hoped that farmers can solve the problem of crop failure, especially crop failure caused by farmer pests. This tool can make it easier for farmers because farmers do not need to use manually operated rice repellents.

\subsection{Innovation device}

(i) This tool does not use a laser sensor and LDR which can cause the tool not to work optimally. However, this tool uses a Passive Infra-Red (PIR) sensor which can be used in the design of motion detectors.

(ii) This tool is already based on a microcontroller that does not require internet such as tools based on the Internet of Things (IOT). Because from what we observe, the condition of farmers in Indonesia and the field conditions in the form of rice fields It is very difficult if this tool is based on loT.

(iii) This tool uses a solar panel as a voltage source, so there is no need for a power cord or socket to run this tool. This will make it easier for farmers to repel pests and reduce the risks of losses.

\subsection{State of The Art}

Below are several journals and theses obtained from the website which contain research that has been carried out by several authors related to the technology to be developed. The research entitled "Implementation of Bird Pest Repellents in Rice Fields Using Ultrasonic Waves Based on the ATMEGA168 Microcontroller" provides an output in the form of a pest repellent that works by using a laser and LDR to detect the movement of living things (bird pests), buzzer to repel bird pests by emitting an ultrasonic sound, an LCD to display the number of sound waves emitted from the buzzer and the ATMEGA168 Microcontroller as the central control circuit on the bird repellent device (Tuluk, et al . 2014). 
However, this tool still has several weaknesses, such as a sound generator that only uses a buzzer so that it has a sound effect of $82 \mathrm{~dB}$ at a maximum distance of $30 \mathrm{~cm}$, and the laser installation with the LDR must be parallel because if there is a slight deviation, the tool will not work. In addition, this tool can only be used to control bird pests, so it is still less effective if used to repel pests in rice fields which consist of various types of pests.

The research with the title "Internet of Thing (IOT)-Based Rice Repellent Model" produced output in the form of an loT-based midges prototype using the ATMega328 microcontroller. This prototype works from the initial stage of providing input in the form of pest movements that will be captured by the sensor. This tool can work automatically or manually driven through a web controller that has been designed. To run the prototype, an internet network is needed which is used for monitoring via the web using a LAN (Local Area Network) so that the coverage of monitoring via the internet is still limited.

Research with the title "Design of a Pest Control Device for Rice-Eating Bird Pests (Oryza Sativa L.) Electrical Mechanical System" produces an output in the form of an automatic pest control device. The way the automatic controller works in this research is by moving a mechanical wheel that is rotated by a dynamo. The source of dynamo power comes from electrical energy. The wheel mechanics after being moved will move the mechanical rod up and down. The movement of the mechanical rod will move the whole rope simultaneously so that the rope will move the objects that are hung to startle the birds while in the rice plants.

\section{CONCLUSION}

An automatic rice repellent is a tool that serves to repel farmer pests automatically, in the form of birds and mice. This tool, based on Arduino technology and sensors, uses a DC motor coupled with a bell and uses a buzzer feature. After a deeper review, the effectiveness and benefits of this tool are indeed numerous and of high use value, especially for farmers. For example, if the rice crop is protected from farmer pests, farmers will get maximum harvest profits, the rice supply will be stable so that the government does not need to import rice from abroad, the regional economy will improve, and as consumers, the price of rice may fall because the rice supply is stable. The author is fully aware that this paper is still far from perfect. Therefore, in the future, we will develop this journal article in more detail and focus on more and more accountable sources. Constructive criticism and suggestions from readers are needed by the author.

\section{AUTHORS' NOTE}

The authors declare that there is no conflict of interest regarding the publication of this article. The authors confirmed that the paper was free of plagiarism.

\section{REFERENCES}

Rainiyati, and Aryanda, A. (2015). Pengaruh pemberian kombinasi pestisida nabati terhadap hasil tanaman padi (oryza sativa I.) Varietas inpara-3 secara sri (the system of rice intensification). Bioplantae, 1(1), 1576-1580.

Sayuthi, M., Hanan, A., Muklis, and Satriyo, P. (2020). Distribusi Hama Tanaman Padi (Oryza sativa L.) pada Fase Vegetatif dan Generatif di Provinsi Aceh. Jurnal Agroecotenia, 3(1), 110. 
Tuluk, E., Buyung, I., and Soejono, A. W. (2017). Implementasi Alat Pengusir Hama Burung Di Area Persawahan Dengan Menggunakan Gelombang Ultrasonik Berbasis Mikrokontroler Atmega168. Respati, 7(21), 121-134. 